\title{
GOOD PRACTICE IN CROATIAN SOCIAL POLICY - RECCOMENDATIONS FOR THE COUNTRIES OF THE EUROPEAN UNION
}

\author{
Ida Mahmutefendić \\ Faculty of Humanities and Social Sciences, University of Rijeka, \\ Sveučilišna avenija 4, HR-51000 Rijeka \\ E-mail address: ida.mahmutefendic@domzdravlja-pgz.hr
}

\begin{abstract}
Social policy has the ideal of cohesion and inclusiveness of all citizens, but it has to "play" an active role in creating opportunities for them. It encopmasses in itself primarily a balance between economic efficiency and social solidarity distribution, and strives towards a consensual social model in which the government and the opposition generally agree on the fundamental priorities of society.

Starting from July 1st, 2013, Croatia has been a member of the European Union. What experiences can that country bring to European Union? In spite of the differences between the European countries becoming more and more expressed and bigger, there is a common element: a conscience that social justice and social reconciliation could contribute to an economical development and that are not just an expense; but the opposite: an economical development that must contribute to social reconciliation.

In the process of the preparation for this work and during the process of its realization, I used the methods of reading a lot of literature, including professional books, professional journals and legislation literature. Social policy has been for years one of my major fields of interest, so some facts I knew already.

My research goal is to examine the development so far of the social policy in Croatia, to detect the most important conditions which are necessary to develop high-quality social policies, to discover which are strong sides, and which are weak sides of the Croatian social policy, and therefore what is important to strongly develop, and what is redundant and/or old-fashioned, to throw away or neglect.

Keywords: economical development, European Union social policy, welfare state
\end{abstract}

\section{INTRODUCTION}

Social policy is one the most imoportant state policies because it covers the most influential areas in politics, such as economy and demography, but also leads the way a state wants to follow. The resources are limited, so therefore we meet with 
the problem of their distribution. In the following text my goal is to try to examine development so far of the welfare state and the social policy between the borders of the European Union, since Croatia has been a member state of the European Union since July 1st 2013, development of the welfare state within Croatia, then I shall try to give an overview of the current situation in Croatia, including an overview of some general data of citizens of Croatia, and some very important data related to social policy, such as employment and unemployment insurance, tax policy, the pension system, health care, housing, education, protection of persons with disabilities and social entrepreneurship.

At the end, I shall try to examine the question of responsibility of the welfare state for the quality of life of its citizens, and to examine perspectives of social policies in the European Union.

What was the development of the welfare state until now? The Court of the European Union took an important approach in Erich Stauder v. City of Ulm (1969) ${ }^{1}$, which showed a switch from the previous prevailing economy and dealing with the common free market to the field of human rights. The above judgment pursued the preservation of people's dignity in an unenviable position, depending on the help of others.

That Court's interpretation of the Commission's Decision completed a legal maneuver, left by the legislature, and has demonstrated excellence in the teleological interpretation of the regulations. Although there is relative age of the said Decision, in the European Union progressivity in the interpretation and application of human rights, but also the understanding of the sense of social policy, however, has not gone so far that the Union can boast considerable progress, one of the indirect indicators of this is the fact that the Republic of Croatia, and even some other countries such as Romania and Bulgaria did not have to meet the demanding requirements in negotiations to join the European Union.

It should be noted that in the early 1980s, Europe began intensive engagement in social issues, mainly fuelled by the entrance of poorer countries like Greece in the year 1981, and Spain and Portugal in the year 1986 into supranational formation, but also appreciable strengthening of the Left in Europe. The social trend has slowed in the early 1990s when it began during the simultaneous development of trends in the context of dominance of neoliberal ideas. With the Maastricht Treaty in $1991^{2}$ The European Union has defined its economic criteria, which set preconditions for far-reaching reduction of social rights in the European Union (Stubbs, Zrinščak, 2005, p. 160).

In contrast, the Treaty of Amsterdam, in May 1999, expresses continuous construction of a social Europe ${ }^{3}$. The period of the 1990s was marked by and more

1 Special significance of this case is the same as the Court of the European Union found that the fundamental human rights are part of the general principles of European Union law which Court is authorized to interpret and apply. In this case, decision of the Commission of the European Communities was set disputed, which is the sale of butter at reduced prices for certain categories of the population, depended on establishing the identification of beneficiaries of social assistance (Erich Stauder v City of Ulm, 1969).

2 Entered into force on 01.01.1993.

3 For the amendments to Article B of the Treaty on European Union, emphasized the promotion of economic and social progress and a high level of employment and to achieve balanced and sustainable development, to strengthen economic and social cohesion. 
committed to discussing the issues of poverty and social exclusion, and consequently the same European Council in 1992 issued a recommendation to the Member States in which it pointed out that the risk of social exclusion and poverty had become more dominant and diversified over the past decade, and that member states had to recognize the basic right of people to adequate resources and social assistance to live in a dignified manner (Stubbs, Zrinscak, 2005, p. 161).

The fight against social exclusion found for the first time its place in the Treaty of Amsterdam, which relates primarily to the promotion of vulnerable groups outside the context of employment policy. The work was noted as a link to social structures, which hinders the formation of social isolation, but in spite of that people can be isolated from the economic, institutional and civil society ${ }^{4}$.

The Treaty of Amsterdam introduced another extremely important innovation that marked a milestone in the development of social policy: the open method of coordination ${ }^{5}$. Primarily, this model was to define common interests of the member states of the European Union, to define a national policy that will serve the achievement of these goals, as well as to provide a system of control based on reports of developments achieved by the Member States.

Five policies of social inclusion in the European Union outlined the elements of open coordination: common objectives on poverty and social exclusion, national action (two-year) plans against poverty and social exclusion, joint memoranda on social exclusion (which primarily depict the situation and political priorities related to poverty and social exclusion in the Member States of the European Union), a joint report on social inclusion (response indicates the various bodies of the European Union on national action plans), and finally, the EU social inclusion indicators, which conventionally comprise three levels: ten primary indicators of financial poverty and material deprivation, employment, health and education, then secondary indicators, complementing the primary, and they also work them out in detail, as well as indicators that countries themselves decide to include in their national action plans, which help to interpret the primary and/or secondary indicators (Stubbs, Zrinscak, 2005, p. 163).

Social protocol, embedded in the body of the Amsterdam Treaty, has developed a social dialogue to a level of power and social control; based on the same series of agreements followed on the issues of the right to work in conjunction with the work: maternity leave, contracts to work temporary and part-time, work councils, and the number of working hours.

Within the Lisbon Strategy agreed at the European Council in the year 2000, the fight against social exclusion has become a legitimate area of the European Union. Aspirations like striving for stronger social cohesion and for the modernization of the European social model would be accompanied, of course, with a number of reforms, but many of them, as it is known, however, remained unre-

4 Article 118 Paragraph 1 Item 4 of the Treaty of Amsterdam states that the Community shall support and complement the activities of the Member States, inter alia, in the area of integration of persons excluded from the labor market, and Article 118 Paragraph 2 determines the jurisdiction of the Council as regards the adoption of measures aimed at encouraging cooperation in order to combat social exclusion.

5 OMC, Open method of co-oordination 
alized: the middle layer has begun to lose its identity and existence, the distribution of social wealth has become more unequal and unjust, there is a high level of long-term unemployment, because of the impact of capital and state in the public sector, the share of women in the labor market has reduced, and regional inequalities have become deeper. However, it should be noted that, contrary to the above criticism, which underlies it, the observed are primarily neo-liberal, non-interventionist capitalism, there are authors who believe that the European Union is today more engaged on issues of social policy than ever in its history, also creates certain policies, and in addition, expands social policy interests in the European Union, including pensions and health care .

The European Commission in its decision of May 2003. announced problems of social exclusion, pensions and health care in the European Union, whose basic meaning is to set common goals. The first national report on the above items were created in year 2006 .

\section{DEVELOPMENT OF THE WELFARE STATE WITHHIN CROATIA}

Since the Agreement of Stabilisation and Association, signed on $10^{\text {th }}$ September 2001, in principle, does not cover the area of social policy, the two reports by the European Union in 2002 and 2003 indicated the problematic level of financial support of civil society, as well as the unsatisfactory relationship between civil society and the Government, and the Government and trade unions.

In the year 2003, Croatia ratified the European Social Charter and its three Protocols, adopted within the Council of Europe ${ }^{6}$. Heavily influenced by the World Bank, Croatia in 2001. finished the complete reform of the pension system.

In the year 2002, Croatian Government enacted the program in aim to combat poverty and social exclusion. This document was written by representatives of various government agencies, a group of experts from various institutions: Department of Social Work at the University of Zagreb, the Croatian Employment Service, the State Institute for the Protection of Family, Motherhood and Youth, and the Ministry of Health and Social Welfare, as well as other ministries. The greatest value of this program is to focus on very important and topical issues of poverty and social exclusion, with an indication of the tasks of the various government agencies in reducing poverty rates. The same document states that the number of poor people in the world has not reduced, in spite of the visible improvement in some areas of living standards, such as access to health care, basic

6 The particular importance of the European Social Charter is in determining the rights and freedoms: the right to housing, which would reduce the problem of homelessness, the right to health, including accessible and effective health care for the entire population, but also the elimination of occupational hazards, which guarantees the right to health care and safety, the right to free primary and secondary education, including special measures for foreign residents, as well as specific measures for the integration of children with disabilities in regular education, rights related to labor and employment issues, which relate primarily to just conditions concerning wages and working hours, also prohibition of forced labor and the prohibition of work for children younger than 15 years, and rights related to collective bargaining, and the prohibition of discrimination (European Social Charter, 1961). 
education, reduction of illiteracy and child mortality, as well as the increase in life expectancy. The program lists the tasks such as developing national strategies to reduce poverty (especially absolute), developing methods of measuring poverty, and ensuring the basic needs of the population. It is particularly noted that a significant contribution in the fight against poverty must be given by civil society organizations, private resources and university research organizations. Referring to the project Analyzing this, certainly an important document of the Croatian Government, we should take into account the overall context in which it occurs; government at that time took a coalition led by the Social Democrats, and it was a post war period, which left a particularly profound changes among the Croatian citizens, of which a fair number faced with the problem of meeting basic needs. As a subject of attempts to repair such a situation, the particular importance was the social welfare system and help, but also civic solidarity and international humanitarian aid.

The main objection to the program above is that the majority remained at the declaration level, and was not based on a comprehensive and relevant data. In the final part of the program it was concluded that the tripartite body was established to monitor the implementation of the same, which will annually report to the Government on the results and possible changes. Although the body is established, no report has not yet been forwarded to the Government.

In this context it should be mentioned, as interesting and important, Opinion of the European Commission (2004), in connection with Croatian candidacy for membership in the European Union, the same is mentioned "generous" welfare system in comparison with the size of the economy, but also states that it is necessary to introduce internationally comparable quantitative and qualitative indicators of social exclusion and poverty, as well as methods for their calculation (Stubbs, Zrinscak, 2005, pp. 172-173).

\section{OVERWIEV OF THE CURRENT SITUATION IN CROATIA}

In accordance with the estimated data of the Central Bureau of Statistics (2010, 2011), the average number of Croatian citizens in the year 2011 amounted to $4.418 \mathrm{mln}$. Gross domestic product per capita in the same period amounted to 10,394 euros, and the average net wage rate 5,343 kunas (7,679 gross). The consumer price index due to the comparison in 2009 and in 2010 amounted to 101.6, while the coverage of imports by exports was $58.8 \%$.

The proportion of illiterate people is evidently decreasing over the years, and examining the results of the census, we see that the illiteracy rate in the Croatian population in the year 1961., when it stood at $12.1 \%$ (the percentage of illiterate women was $17.2 \%$, while the percentage of illiterate men was 6.4\%), in 2001 was reduced to $1.8 \%$ (the percentage of illiterate women was $2.8 \%$, while the percentage of illiterate men was $0.7 \%$ ).

In 2010, 47.630 pupils have completed primary education, secondary education 44.810, while in the same year at universities in Croatia, 9.670 students graduated 
(in professional programs), and 22.708 (university studies). Last year Croatia signed up 1.077 new Master of Science, Master's and university specialists (including 599 women) and 838 new PhDs (including 428 women) (Central Bureau of Statistics, 2010).

The total number of employees since 2008 until 2010 decreased (in the 2008 this number was $1.555 \mathrm{mln}$ workers, while in the 2010 the total was $1.432 \mathrm{mln}$ ), but the proportion of the working age population since 2008 until 2010 year grew (in 2008 it amounted to $3.68 \mathrm{mln}$, in 2009 to 3.708 .000 , and in 2010 to 3.752 .000 ).

The final consumption expenditure grew in recent years, so in 2007 average household annually allocated 74.006 kunas to cover its needs, in 2008, this amount consisted of 74.524 kunas, while in 2009 it rose to 76.188 kunas. Examining the structure of personal consumption, we note that the largest share related to the purchase of food and non-alcoholic beverages (32.06\%), housing and energy $(14.39 \%)$ and transportation $(10.98 \%)$. The smallest share of the above paragraph is taken by education, which in 2009 fell by an the amount of only 1.00\% (Central Bureau of Statistics, 2010).

The estimated risk of poverty for a single household in 2007 amounted to 23.969 kunas, in 200824.311 kunas, while in 2009 it amounted to 26.703 kunas. The estimated risk of poverty for a household of two adults and two children in 2007 amounted to 50.336 kunas, in 2008 to 51.054 kunas, while in 2009 it amounted to 56.076 kunas. CBS does not specify how many of our citizens were covered by these thresholds, but states that in 2008 there were recorded 392.769 welfare recipients (of which 80.593 minors), this number in 2009 amounted to 391.549 (of which 77.294 minors), and in 2010 to 404.306 (of which 81.433 minors) (Central Bureau of Statistics, 2010).

In 2010 there were 1.207 users of children's homes (located in a total of 52 children's homes), homes for the elderly and infirm 15.283 (located in a total of 196 institutions), in homes for the mentally ill elderly 3.889 (located in a total of 29 institutions) and 85 placed in homes (2 total institution) for alcohol, drugs and other narcotics. The Gini coefficient in 2007 amounted 1.28 in 2008 it was 0.29 and in 2009 it was 0.27 (Central Bureau of Statistics, 2010).

From the current state of social policy in the Republic of Croatia, one can easily spot several major drawbacks, whose correction is also a conditio sine qua non for the further development: there is no strategic direction in social policy, a series of attempts to solve the problems in this area failed (for example, the role of government through social welfare centers, and the role of government entities: civil society and the private sector), there are no comprehensive mechanisms of social planning, and coordination of different policies is also not developed.

It is clear that the fight against poverty and social exclusion cannot be limited only to the social assistance system, but it also requires good coordination with many other disciplines, and development and prosperity of these disciplines. Above all, we are talking about labor legislation and wage policy, politics of employment and protection against unemployment, tax policy, the pension system, health care, housing, education, family policy, social assistance and welfare, and the domain of civil society. These domains, we will try to show below, keeping in mind the objectives and spatial limitations of this study: 
Employment and unemployment insurance. This domain is perhaps the most important in the fight against poverty and social exclusion; work is not only a source of income for citizens, but also the basic means for a decent life and a decent standard of living. Pursuant to the Croatian Employment Service, in 2011 in Croatia, the largest number of registered unemployed was in Split-Dalmatia County (43.261 or $12.9 \%$ of the total number in Croatia), the City of Zagreb (41.562 or $12.4 \%$ ) and Osijek-Baranja County (35.387 or 10.5\%) and lowest in Lika-Senj County (3.872 or $1.2 \%)$. The highest number of unemployed in that year was between the ages of 25-34 years (25.5\%) and $45-54$ year $(22.5 \%)$. The total number of unemployed in the same year, women accounted for $53.5 \%$ (180.100 people), and men $46.5 \%$ (156.311 people) (Central Bureau of Statistics, 2010).

The Croatian Government adopted in 2011 The National Employment Promotion Plan (2011, p. 86). For the implementation of measures within the competence of the Croatian Employment Service (support for employment, self-employment and training and education for the labor market, public works, training for the operation and support for the preservation of jobs) secured 171 mln kunas. It also secured $6 \mathrm{mln}$ for the National Programme for the Roma people (The National Employment Promotion Plan, 2011, p. 87). On the day of writing this paper (12.02.2014), the official number of unemployed in the Republic of Croatia has reached 382.000 (Croatian Employment Service, 2014), so it is easy to conclude how these measures were successful.

Tax Policy. Progressive tax systems and abundant social transfers reduce inequality and poverty. Taxation policy is determined independently of the European Union, and the EU-wide harmonized tax only that part which is related to the single market to all economic operators across the EU. The aim is to have equal conditions in the market competition. The obligation is to comply with the acquis in the fields of indirect taxes, value added tax and excise duties on fuels, tobacco products and alcoholic beverages.

On the day of writing this work Croatia still has had a great turbulence just in this domain, and the official explanatory justification of the Minister of Finance of the Government is the need for deficit reduction. Property taxes were announced, taxes on interest on savings, etc.

The pension system. Due to the continued deterioration of the ratio between the number of insured persons and pensioners (on the day of writing this paper, that ratio is 1:1.18 in favor of the insured (Croatian Employment Service, 2014), the pension system hardly fulfills its fundamental role. Poverty affects particularly those layers of the elderly population who receive no pension. The average old-age pension for 40 or more years of service totalled 3479.08 kunas net, and its share of the average net salary in Croatia in November 2013 (5.634 kunas neto) was $61.75 \%$ (Croatian Employment Service, 2014).Taking into account the above information, as well as the age of this group, but all the difficulties associated with it, we can conclude that this is a very high-risk group for entering the zone of poverty.

Health care. The Croatian health system is characterized by dissatisfaction with the system and the high costs of the system. There is still unequal access to 
health care and its lack of comprehensiveness, and thus efficiency (Stubbs, Zrinscak, 2005, p . 166). The combined use of health services by public health institutions and private health services most affected is poor class population. During the presentation of the draft national strategy for the development of health care by the year 2020, Ranko Stevanovic pointed out that the year 2011 recorded in the activities of family medicine (compared to in 1990) $81 \%$ less systematics, periodical check-ups of adults, $45 \%$ fewer home visits by physicians or $90 \%$ fewer home visits to other health care professionals 7 . These data, along with an increasing decline in living standards and generally unhealthy living conditions, support the risk of many diseases (Ostojic, 2012).

Housing. A flat or a house is a primary human need, and from this fact derives its social meaning. This causes a variety of national significance and social assistance and support, therefore housing policy is not only part of the market between supply and demand. Social housing entails state intervention in housing consumption, and includes the construction of social housing for the target groups, subsidized rents and housing costs.

In accordance with the principle of subsidiarity, in the system of the European Union member states are left to the design and implement their own housing policies. Following the same theme, the national housing policy framework in the EU is different between the states, and the most developed housing policy is in France and Denmark. The leaders have developed an active role in investing in housing, and managing the social rents.

The cost of housing in the total consumption of the population in Croatia is extremely high, according to data from the Central Bureau of Statistics, the rate increased risk of poverty of tenant is 20.2\% (Central Bureau of Statistics, 2011). In Croatia, there is still no systematized development of housing policy, including the right to accessibility and affordability of the apartment, but also to quality and standard of living.

Education. As the quality of employment politics is the best expression of social policy, so education is the best means of quality employment, and thus the route out of poverty. Since starting the basics are all not the same, especially to the social democratic government should be in order to equalize the chances and opportunities to acquire quality education to all interested parties. It is well known that individuals with no education more often remain poor, and children from poor families rarely acquire higher levels of education. Special aggravating circumstances of such children is the family environment in which predominantly prevalent language is scarce, and there is a small chance of gaining social skills. The clear correlation is between educational attainment and unemployment. It should not be exempt from the sight of any new circumstances of market capitalism, which requires lifelong learning, but also the conditions of the labor market in which individuals are often forced to train for new jobs to exit the status of unemployed. Pursuant to the Croatian Employment Service of the year 2011, the vast majority

7 In terms of lack of availability, specifically refers to the isolation of specific geographic areas in Croatia, but also the long waiting lists that still exist, despite repeated attempts by powerful Ministry of Health to address this problem. 
of the unemployed accounted people with high school level of education - $62.8 \%$ (34.9\% with three-year and $27.9 \%$ with a four-year high school). People with lower education constitute $27.9 \%$, and the people with higher education levels $9.2 \%$ of the total number of unemployed (Croatian Employment Service, 2011). The active role of the state is expected towards citizens with incomplete primary education, in terms of offers additional training, additional education or similar.

The equalization of educational opportunities has important significance in accommodation in student dormitories and, in the latter the country bears a large part of the cost of accommodation and food. Equally important, if not more important, are state scholarships which help students (undergraduate and post-graduate) students of lower economic status and protect persons with disabilities. The Ministry of Science, Education and Sport (2013), in accordance with the proposals quota of public universities and colleges, and received reports of students at the competition for the award of government scholarships for regular students of public higher education institutions in the Republic of Croatia and the partial refund of the cost of post-graduate students with disabilities for the year 2013, was approved by the 2013 year a total of 2.187 new scholarships.

Protection of persons with disabilities. The real welfare geared towards people with disabilities is concerned with the right to receive personal disability allowances, the right to receive assistance and care, help and care at home, care outside the family, and employment benefit. In Croatia, the situation on 17th January 2013, 520.437 people living with disabilities, of which 313.217 were male $(60 \%)$ and 207.220 women (40\%) and thus people with disabilities make up about $12 \%$ of the total population of Croatia. The largest number of people with disabilities, these 278.564 (53.6\%), is of working age (Central Bureau of Statistics, 2013). Data on realized compensation to employment suggest that persons with disabilities make a group of people hard-to-employ, indeed, most of these groups receive this benefit for life.

Social assistance. In 2010 in the Republic of Croatia, there was a total of 744.003 beneficiaries of some form of social welfare (of which 157.767 minors (Central Bureau of Statistics, 2010). According to data of the Ministry of Social Policy and Youth (2011), funding for financing social welfare activities are provided mainly from the state budget (about 96\%) (Ministry of Social Policy and Youth, 2011). Due to the large number of unemployed welfare recipients, all social programs of Employment Services, which aims are to improve the educational background and help individuals to acquire certain qualifications or skills are of great importance. The standard fee is determined on an annual basis, taking into account the height of inflation and cost of living increases.

Social Entrepreneurship. With the entry into force of the Law on Social Welfare (2014) in Croatia finally the legal conditions for the development of social entrepreneurship have been created. The concept of social enterprise which integrates the creation of social and economic value has been present theoretically and in practice for a century (Škrtić, Mikic, 2007, p. 153), but only recently, with the development of globalization has it become particularly important. In contrast to the ideology of market capitalism, according to which the primary objective is to 
create the largest possible profit, social enterprise does not reduce that goal, but it is overshadowed by other values, such as creating significant social value in the form of employment, providing necessary products and services, improving working conditions, providing that the tax payment by these entities are still used for social purposes.

From perhaps the most prominent companies in the embedded domain of social entrepreneurship in Croatia, I mention for example Institution for Rehabilitation of Disabled Persons vocational rehabilitation and employment (URIHO) that operates in the City of $\mathrm{Zagreb}^{8}$, a private enterprise for professional rehabilitation and employment of persons with disabilities Lada, company ZAPOS and other entities that employ people with disabilities.

The City of Zagreb has a majority stake, and is the founder of the URIHO, largest organization of this kind in Croatia, which employs more than 500 employees , of which more than $50 \%$ of people are with disabilities. An example of an association which supports environmental goals is certainly Dolphin Dream, which aims to conserve the natural heritage of the Adriatic region (sea, coast and islands). The effect of this association is based on the promotion of environmental awareness, quality of life, the promotion of sustainable development, interactive eco-education and eco-tourism . The association is financed from a variety of sources: donations, government grants, sponsorships and its own resources, and cooperates with international foundations, the business sector, local and national government, as well as the media.

\section{WHY IS THE WELFARE STATE RESPONSIBLE FOR THE HIGH STANDARD OF CARE FOR THE POPULUS?}

The welfare state is based on the assumption that people are interdependent, and that they are able to take care of each other. Some collective entities such as the Amish community consider social welfare provided by the state unnecessary, because they feel that it is not advisable to live with the help of the state, however, they can not deny the interdependence of people, which is actually based on the postulate of the welfare state. The implementation of social policy, at least from an idealistic point of view, certainly is a yearning for a better and fairer world. We cannot go wrong if we compare social science with medical science, with respect to both, in applying their achievements, but none of them is immune from abuse and unintentional failures.

Social policy has the ideal goal of cohesion and inclusiveness of all its citizens, but it has to "play" an active role in creating opportunities and removing barriers when such approaches are ideal. It encompasses in itself primarily a balance between economic efficiency and social solidarity distribution, and strives to

8 URIHO company is engaged in the production of labor-protective clothing and footwear, part of the military equipment and orthopedic appliances and footwear products, leather goods and leather garments, hunting and fishing equipment, cardboard packaging and paper products, printing services and graphic finishing, makes fencing for parks, yard, stairways, balconies, decorative protective grille and doors, tables, chairs, shelves. (Škrtić, Mikic, 2007, p. 162). 
achieve a consensual social model in which the government and the opposition generally agree on the fundamental priorities of society.

For a quality welfare state strong labor unions are indispensable, united in their objectives which have indisputable priority over mere interests, which are in fact partners with the state authorities, since they have, above all, a common cause: the healthy development of their country, which is impossible to achieve without social cohesion and satisfaction of the largest number of citizens.

The construction of the welfare state includes a strong network of services (government, hospitals, kindergartens, schools), which do not require significant financial resources, as claim those who do not know enough about social policy, nor do they have an affinity to it; quality services, especially schools and kindergartens, can be built from modest means and act in modest circumstances, and also act well and be for the benefit of the wider community.

So far the European social model aspires to social cohesion, or the ability of a society to achieve the benefit for all its members, minimizing disparities and avoiding polarization. According to this model, as an ideal, there is the idea of solidarity and community consisting of free individuals, but the idea that such a society provides better economic development.

Certainly negative tendencies in the corpus of the European social model is the internationalization of social policy, according to which the changing of the welfare state is required, that puts the responsibility on the individual. In these tendencies, governments are limited to market imperatives. In this environment, that we are free to call the culture of greed, the imperative of profit maximization and capital accumulation, take precedence over justice and environmental sustainability, and workers lose some hard-earned rights.

It is useful here to make a blitz Einsicht in view of the position and role of the welfare state with the most important positions of current ideologies. Thus the liberal type is mainly focused on the rehabilitation of the poorest sections of society, with benefits from above, from the rich to the poor, limited and low, and reveals a strong market presence in the social sector.

The Conservative type tends to preserve existing conditions, redistribution is horizontal, and there is subsidiarity in social assistance (all of which can be, is dealt at the lowest level). The Social Democratic type tends to reduce social risks, the vertical and horizontal distribution, as its criterion of successful operation of the welfare state is universalism.

Today, however, there are no sharp divisions in practice between different ideological options, because we see the superiority of the idea that globalization is a positive, individual choice, free trade has been encouraged, ideologies are odious, while on the other hand civil society has an important role, and the emancipation of women is an essential prerequisite for development. Special similarities in these positions we see in the social democratic and liberal vision of reality.

Perhaps the greatest scope of the welfare state is that it has the power to change the quality of life of citizens. Leveraging their lives to have a high level of dignity and satisfaction, but also to make sense of the existence and activities of the state, which is not set as the authority to impose, but resemble some kind of partnership. 
It is possible that these ideas sound like fatamorgane and even passé, but what is to be said for some other ideologies, which have been aspired, and soon proved, to put it mildly, inappropriate for mankind?

To summarize in terms of offers the best options for achieving the welfare state, the question appears which method is the most effective in achieving this goal? Is it achieving more money for any purpose provided for in the social policy? Or maybe development of a structure of money distribution for social needs, in other words, the quality of prioritization? Should unique supply of social measures be valid, or based on achievements? Or quality, which means comprehensive, just and thorough implementation of the control of its money spending allocated for social purposes?I think that we should give priority to the second option. The system of supervision and punishment in an ideal projection should be seen as a transitional necessity, given that the final solution, however the relationship of mutual trust, state and the citizens, because only such an attitude towards their respect may be part of the ultimate criterion of satisfaction of citizens, which is, let us not forget, the basic objective of the welfare state.

\section{PERSPECTIVES OF SOCIAL POLICIES IN THE EUROPEAN UNION}

Theories of the welfare state in countries of Western Europe, and the countries of Eastern Europe, the issue is of the influence of trade unions and social democracy to build a model of the welfare state. In this regard, the states of South East Europe are characterized by weakness of trade unions and left-wing political parties, the latter generally have imprecisely formulated flexible programs without foundation in civil society, and their political positions are not clearly defined. The parties often join in a coalition and their main goal is gaining and maintaining political power. Earlier inevitable networking between unions and political parties no longer exists, now these links are much weaker and more informal. The common view of experts is that the model of the welfare state that governments in Western Europe have cannot be mapped to the states of Central and Eastern Europe.

The situations are different, however, in some European systems of social protection. In most states, however, the established view that the welfare state is now overloaded, inefficient or compromised. Some consider that the welfare state should be radically reduced, others that it should be strengthened, and a third have the viewpoint that should be gradually restored. It is possible to identify two different types of European regimes of social protection. Following this, we see that it is impossible to conceive a global strategy for social reform on a pan-European level. With the exception of Scandinavia and Great Britain, the social division of responsibilities between the states, market and family in the past few decades, has changed just a bit. The postwar model could rely on the stability of the family structure and well-functioning labor market, and thus could provide a substantial part of social protection to most people throughout most of their lives. The main social risks are concentrated mainly in numerous families and in the elderly. Euro- 
pean welfare states were giving priority, in addition to health, and maintaining income or pensions.

Reform of the current pension regimes is faced with the dilemma of whether future generations of retirees will be able to collect such property, whether it will work on their personal initiative (work and savings), whether it would achieve through redistributive mechanisms of public pension funds. In addition, many of today's workers can expect prolonged or frequent periods of unemployment, associated with unsecure jobs.

The market cannot assume the systems of care for children and the elderly, who will also be accessible and of good quality. In other words, public assistance or direct offer of public services are the first requirement of any reform. Based on this logic are changes in priorities in social protection in favor of family services. How does the European welfare state in the 21st century look ? To advocate the privatization of the welfare state, or the return of the family and the local community, as well as any defense of the status quo, seems to be inappropriate. Also, if the main public priority is control of public expenditure, consideration of new principles of justice can seem pointless.

So what would be desirable in terms of limited resources? What are the common goals that have to be accomplished? What do we want to achieve? In short, what should be our common standards in terms of justice, equity, guarantees of collective and individual responsibility? The Maastricht convergence criteria commitment to cost reduction, does not open good opportunities for short and costly reforms. The dilemma, related with resources, strongly dominates if we take into account the new inequalities and new social risks. Therefore, we can be focused on the optimization of a system of social protection as defined re-affectation funds, which achieves maximum efficiency and that nobody loses (example: deregulation of wages that will most likely increase the inequality of income). Another option is the principle of justice of John Rawls, who insists that no gain is justified if it is not followed by the benefits to the poor and weaker.

\section{CONCLUSION}

Social policies of the states, members of the European Union, differ significantly; those states have their traditions, their different possibilities and their different priorities.

Croatia has founded some of the very important bases for the good development of social policy, but the need to lift the effort to a higher level is very visible. Since the point of the high-quality welfare state is not only the fact that every citizen, or at least most of the citizens, have covered their basic needs, for example the need for food or home or at least shelter, but also the need to develop and maintain the decent degree of dignity. That degree can be reached with the help of several conditions, and one of them is certainly the awareness of the usefulness for the society those citizens live in; that is why the employment policy and social entrepreneurship are so important, and it is obvious that Croatia has to do a lot to reach those goals. 


\section{REFERENCES}

Central Bureau of Statistics (2010). Retreived from www.dzs.hr

Central Bureau of Statistics (2011). Retreived from www.dzs.hr

Central Bureau of Statistics (2013). Retreived from www.dzs.hr

Croatian Employment Service (2014). Retrieved from http://www.hzz.hr

European Social Charter (1961) Retreived from http://www.coe.int/t/dghl/monitoring/ socialcharter/default_en.asp

Law on Social Welfare (2014). Retreived from http:/ /www.zakon.hr/z/222/Zakon-o-socijalnoj-skrbi

Opinion of the European Commission (2004). Retreived from http:/ / eur-lex.europa.eu/legal-content/ EN/TXT/?uri=CELEX:52004DC0257

Stubbs, P., Zrinščak, S. (2005). Extended social Europe? Social policy, social inclusion and social dialogue in Croatia and the European Union. Retrieved from http:/ / www.ssoar.info/ssoar/bitstream/handle/ document/6143/ssoar-2005-stubbs_et_al-extended_social_europe_social_policy.pdf?sequence=1.

Škrtić, G., Mikic, M. (2007). O socijalnom poduzetništvu u svijetu i u Republici Hrvatskoj [A social enterprise in the world and the Republic of Croatia]. Zbornik Ekonomskog fakulteta u Zagrebu, 5(1). 153-163.

The National Employment Promotion (2011). Retreived from http://hrcak.srce.hr/index. php?show=clanak\&id_clanak_jezik=105688

The Treaty of Amsterdam (1999). Retreived from http:/ / www.eurotreaties.com/amsterdamtreaty.pdf

The Treaty of Maastricht (1991). Retreived from http:/ / www.eurotreaties.com/maaastrichtec.pdf 